\title{
Mapping association: Analysis of elaboration skills through creative mind mapping on the subject of environmental change
}

Gufron Amirullah $^{1 *}$, Budhi Akbar ${ }^{1}$, Rizkia Suciati ${ }^{1}$, Susilo $^{1}$

${ }^{1}$ Biology Education, Universitas Muhammadiyah Prof. DR. HAMKA, Jakarta, Indonesia 13830

*Email: gurfron.amirullah@uhamka.ac.id

\begin{abstract}
This study aims to measure the value of the relationship between elaboration skills and creativity through mind mapping on the subject of environmental change in high school students. For that purpose, a total of 39 students were involved in this study. Participants were determined by convenience sampling to work on the instrument test and non-test issues. The test instrument is in the form of a description to measure the development skills and a non-test instrument in the form of a mind-mapping section to measure student creativity. Data were analyzed using a simple regression analysis after being entered on the Excel encoding sheet. This study shows a correlation between skill development and creativity through mind mapping of material changes in the environment $(y=30,977+0.7047 x)$. The average score for student development and creativity in mind mapping was in the category 60.83 and 73.84 respectively. Based on the results of data analysis, the value of $F(0.82<2.98)$ is obtained, so the two variables are classified as linear. This study can inform the assessment of the relationship between good development skills and creativity in the creation of new ideas through a mind map.
\end{abstract}

Keywords:

Climate Change; Creativity; Elaboration Ability; Mind Map;

Article Received: 18 October 2020, Revised: 3 November 2020, Accepted: 24 December 2020

\section{Introduction}

Secondary education has a key role to play in creating high-quality students who can think critically, creatively, logically and take the initiative to address issues in society as a result of the development of science and technology (Permendiknas, 2006). Science learning is a forum for increasing knowledge, skills, attitudes and values (Fatonah \& Prasetyo, 2014). Science is concerned with how to systematically discover and understand nature, including not only the mastery of the collection of knowledge in the form of facts, concepts and principles but also the process of discovery (BSNP, 2006; Nofiana \& Julianto, 2018). Creativity in learning can train students not to depend on others. If someone has high creativity, that person will be more creative and produce something positive because the creativity of a student in learning will greatly influence the student to obtain success (Jahnke et al., 2015). Students who have high creativity will have a broad view of their learning so that this will have an impact on the high and low quality of student learning (Widyastuti et al., 2019).

The survey reports that the ranking of education in Indonesia is still low. It can be seen that Indonesia is ranked 44th out of 47 countries (TIMSS, 2015). Education in Indonesia still emphasizes the development of intelligence rather than the development of creativity, even though both are equally important to achieve success in learning and in life (Munandar, 2014). thinking skills that can produce quality students with divergent thinking, namely creative thinking (Leeds et al., 2018; Xu \& Pang, 2020). Creative thinking can be defined as an exploration activity to give rise to new ideas, new possibilities, to create something new, based on the authenticity of the results (Kisirkoi \& Mse, 2016). One of them, which includes creative thinking skills, is the development of skills (Yang et al., 2016).

The ability to elaborate is an indicator of the ability to think creatively, which includes the ability to enrich and develop an idea, a product, details of an object, and an idea or situation so that 
it becomes more interesting (Jankowska et al., 2019; Pillay et al., 2020; Yang et al., 2016). Therefore, students can be trained to work on any project, assignment or bill in order to produce more exciting and complex thoughts and products. The ability to think elaborately can be measured if students can develop their creativity in an optimal way (Hsu et al., 2014). The elaboration abilities that students have through science learning can produce students who can express their ideas or ideas in order to produce a maximum potential for creativity (Kalyuga, 2009). Student creativity products such as mind mapping can motivate students to improve learning, speed, ability to think more structured and encourage the creation of bright and inspiring ideas to solve problems (Murray, 2016). Mind mapping is proven to be able to solve all children's learning problems (Pillay et al., 2020).

Mind mapping is a technique for developing more creative and innovative thinking so that what is emphasized in science learning is the strengthening of concepts that are mapped to the individual's way of thinking (Čančer, 2014; Malycha \& Maier, 2017). Mind mapping has been proven to provide students with better creativity in learning Biology (Darusman, 2014). The application of the learning method with mind mapping has a significant effect on science learning because there are central concepts that require students to be more creative and work together in groups. So that when working on the post-test questions given by the teacher, it is easier to do and in general, can improve learning outcomes in learning Biology (Heriadi, 2015). Although mind mapping significantly gave positive results in science learning, the relationship between elaboration skills and mind mapping was rarely reported.

Furthermore, students' elaboration skills are essential to encourage student creativity. Thus, this study is designed to examine more deeply the relationship between elaboration skills and student creativity by applying the mind mapping method in learning. This article provides a more in-depth review of the importance of applying mind mapping in motivating students to think creatively.

\section{Method}

\section{Participants}

This study explores the relationship between the two variables through a correlational study. A total of 39 students (male 20; female 19) were involved to fill out the test and non-test answer sheets. They were selected by convenience sampling in high schools in Indonesia. The criteria determined participants that they were taking the science department in the second semester. The test instruments were in the form of essay questions used to measure students 'elaboration abilities and non-test instruments in the form of creativity rubrics in mind mapping to determine students' creativity in making mind mapping.

\section{Instruments}

The ability to elaborate is measured by an instrument which includes five indicators, namely 1) adding or enriching the details of an object, idea or situation; 2) detailing details; 3) expanding ideas; 4) perform detailed steps; and 5) adding lines, colours and details (parts) to one's own or other people's drawings. The percentage of elaboration ability of each indicator is presented in Table

Table 1. Percentage of Elaboration Ability

\begin{tabular}{lcc}
\hline \multicolumn{1}{c}{ Indicator } & Percentage (\%) & Information \\
\hline Add or enrich the details of an object, idea or situation & 70,51 & Enough \\
Breaking down the details & 66,03 & Enough \\
Expanding ideas & 63,46 & Enough \\
Perform detailed steps to solve the problem & 48,07 & Very Less \\
Add stripes or colour in detail & 56,09 & Less \\
\hline
\end{tabular}


Data analysis was performed using simple regression to investigate the relationship between elaboration skills and creative thinking in 39 high school students.

\section{Result}

Base on Table 1, the highest average value of elaboration skills that students have is the ability to add or enrich the details of an object, idea or situation with an average percentage of $70.51 \%$ and the ability to take detailed steps to solve a problem. Is at the lowest level, where the percentage only reaches $48.07 \%$ of the student's ability is classified as very low.

\section{Creativity through Mind Mapping}

Student creativity data which is measured in a mind mapping made by each student, includes several predetermined assessment indicators consisting of 10 indicators, namely originality, fluency and flexibility, and elaboration. There are seven indicators of mind mapping assessment, namely relationships (links), the placement of central ideas, the use of images/photos for central ideas, the use of colors, the use of curved lines, keywords, and the use of images other than the central idea. The percentage of creativity by mind mapping can be seen in Table 2 .

Table 2. Percentage of Creativity through Mind Mapping

\begin{tabular}{lcc}
\hline \multicolumn{1}{c}{$\begin{array}{c}\text { Indicators of Creativity Through Mind } \\
\text { Mapping }\end{array}$} & Percentage (\%) & Information \\
\hline Originality & 51,79 & Less \\
Fluency \& flexibility & 66,15 & Enough \\
Elaboration & 69,23 & Enough \\
Link & 66,15 & Enough \\
Central idea placement & 97,95 & Very good \\
Image / photo of central idea & 100 & Very good \\
Color & 72,31 & Enough \\
Curve & 85,64 & Good \\
Keywords & 65,13 & Enough \\
Image other than the central idea & 65,10 & Enough \\
\hline
\end{tabular}

The results presented in Table 2 show the average value of students' creativity in mind mapping the creativity indicator, i.e. the originality with a percentage of 51.79 per cent belonging to the low category, while the elaboration indicator in the next position is 69.23 per cent. Classified in the good category and the mind mapping indicator, the use of images/photos on the central idea is 100 per cent classified in the excellent category.

\section{The Relationship between Elaboration Ability and Creativity Through Mind Mapping Regression Linearity Test}

The results of the analysis in Table 3 show that the $F_{t c}$ value is 0.82 , and the $F_{k k}$ value is 2.98 . This could prove that the value of $F_{t c}<F_{k k}$, it can be concluded that the data for the variable of elaboration ability with creativity through mind mapping are classified as linear according to the linearity testing criteria above. The following is a regression linearity graph for the variable elaboration ability with creativity through mind mapping. 


\begin{tabular}{ccccccc}
\hline Criteria & $\mathrm{r}$ & $\mathrm{db}_{\mathrm{kk}}$ & $\mathrm{db}_{\mathrm{tc}}$ & $\mathrm{F}_{\mathrm{tc}}$ & $\mathrm{F}_{\mathrm{kk}}$ & resume \\
\hline Elaboration Ability & 0,59 & 22 & 15 & 0,82 & 2,98 & Linier \\
\hline Mind Mapping Creativity & & & & & & \\
\hline
\end{tabular}

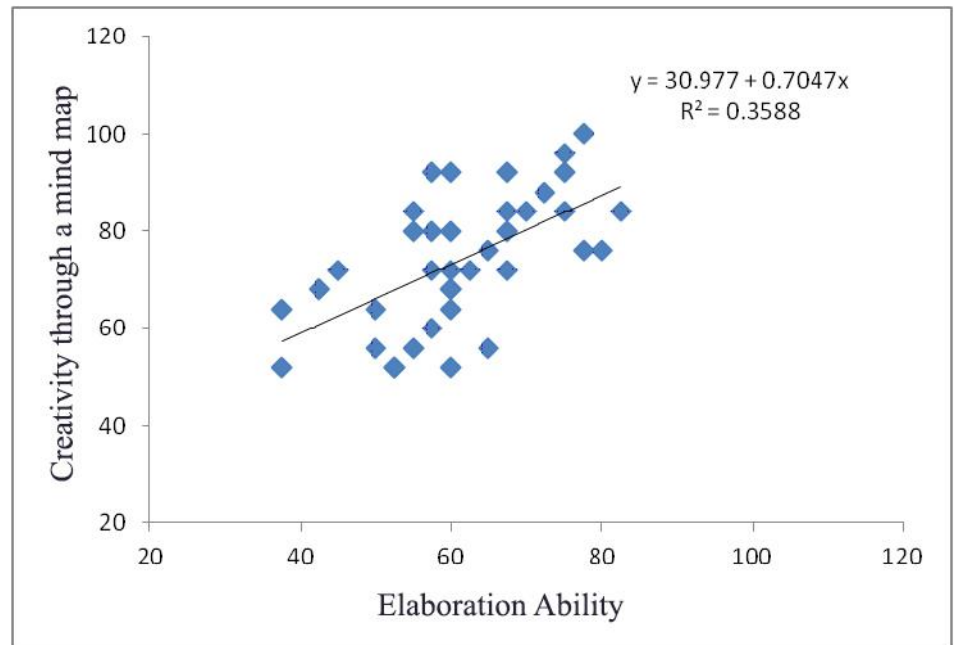

Figure 3. Regression Linearity of elaboration ability with creativity through mind mapping

\section{Hypothesis test}

The results of the calculation of the hypothesis with a significance level of $1 \%$, obtained the data value of $\mathrm{r}=0.599$ at $\mathrm{a}=0.01$ with $\mathrm{N}=39$, it is known that the value of $r$ table $=0.408$. This can prove that the value of $r$ count $=0.599>\mathrm{r}$ table $=$ 0.408 . Thus, based on the criteria for hypothesis testing, it can be concluded that $\mathrm{H}_{0}$ is rejected and $\mathrm{H}_{1}$ Is accepted, which means that there is a relationship between elaboration skills and creativity through mind mapping.

\section{Discussion}

The quality of the achievement of students' elaboration abilities can be seen from the average score obtained as a whole, which is 60.83. The average elaboration ability of students is in a good category, meaning that students are able to answer questions and clarify problem-solving in detail and accurately. The elaboration ability of students who are in the sufficient category is influenced by several other factors, namely habits, time, environment and fear of failure (Olson, 1992). Based on the results of observations from students 'answers, the factors that caused the students' ability to elaborate were sufficient because they were afraid of failing to solve problems. This makes students not confident if students do not believe that they can overcome these problems, then this greatly hinders someone from developing creative thinking skills (Rolia et al., 2017).

A more prominent indicator of elaboration is the ability to add or enrich the details of an object, idea or situation with a percentage of $70.51 \%$ which is in the sufficient category. This can be seen from the student's ability to predict the answers to the questions that have been given, where the ideas put forward have been developed, added, and enriched in detail. The ability to elaborate focuses on the ability to add or enrich the details of an object, idea or situation. Elaboration ability is the ability to develop, add and enrich an object, idea or situation (Kalyuga, 2009).

The indicator of elaboration ability that is in the less category is to carry out detailed steps of $48.07 \%$. The indicator of the ability to elaborate in carrying out steps in detail is the ability to find a deeper meaning to answers or problem solving by carrying out detailed steps (Munandar, 2014). The fact that the indicator of the ability to take detailed 
steps is still lacking can be seen from the answers of students in answering questions. The way students answer the questions given, and students still tend to answer using concepts or explanations that have been given by the teacher and students have not been able to provide detailed answers from those given by the teacher. According to Yunianta (2014), Students are afraid that the answer will be wrong and will get a bad score so that students are still fixated on the concept explained by the teacher. To improve the ability to take detailed steps, the teacher can facilitate students to ask and answer questions according to their opinion in order to spur students to solve problems by taking detailed steps (Wu \& Albanese, 2013).

Meanwhile, the quality of student creativity achievement can be seen from the overall average student creativity score of 73.84 , including the sufficient category, in mind mapping. This means that students have been able to take creative notes using symbols, colors, lines and images that are steps in the development of creativity related to the subject of environmental change. Students' creative abilities are the result of developing new ideas from what they learn to become something new. According to Buzan (2008), mind mapping is the only tool that can be relied on to think creatively and can generate ideas, plan something uniquely. More clearly, some factors affect the achievement of student creativity. Whether or not student creativity develops can be seen from the enthusiasm of students and the environment. The environment has an important role in the development of a child's creativity (Munandar, 2014). Of all types of environment, the family environment has the most important role in the development of creativity. For this reason, it is necessary to have a good relationship between the school and the parents of students to work together in developing student creativity. Sometimes, without realizing it, the condition of the family environment can also hinder the development of a child's creativity, for example, the attitude of parents who limit their children to explore, fantasize and possessive towards children's choices will hinder the development of children's creativity that begins to develop in them (Munandar, 2014). This also applies to teachers in schools, if the teacher shows an attitude when learning restricts students from having an opinion, closing the possibility for students to express ideas and showing their own abilities will hinder students' creativity from coming up (Leeds et al., 2018).

The use of images or photos for the central idea of the mind mapping indicator is in the outstanding category of $100 \%$. It is known from the results of students' mind mapping making; students have been able to put the central idea in the middle. The use of pictures or photos for central ideas helps to stay focused, concentrate and activate the brain to think (Buzan, 2008). Furthermore, the elaboration indicator in mind mapping has a percentage of $69.23 \%$ belonging to the sufficient category. In this indicator, students have been able to make branches using many concepts, and students are able to describe problems about environmental change in depth as evidenced by the ability to create branches with a minimum number of 12 branches. Sternberg (2006), said that elaboration is the ability to describe a particular object and is a bridge that must be passed by someone to communicate their creative ideas.

The indicator of authenticity or originality has a percentage of $51.79 \%$ belonging to the low category. Originality is indicated by responses that are unusual, unique and rare (Filsaime, 2008). The fact is that the indicator of creativity, namely originality, is still very less known from the results of making mind mapping because students have not been able to make mind maps with unique keywords and are not accustomed to using images for central ideas that are different from others. As for the effort to increase originality in mind mapping by familiarizing students with making creative notes, this will make students trained to take creative notes and be able to make mind maps with unique titles (Putri, 2016) 
Based on the data obtained, the results of the calculation of the contribution between elaboration skills and creativity through mind mapping were $35.88 \%$ and an r-value of 0.599 which was interpreted as sufficient (good) and significant. This shows that the relationship between elaboration skills and creativity through mind mapping means that the ability to elaborate affects students' creativity through mind mapping. This fact is intended to increase creativity through students 'mind mapping, which can be done by increasing students' elaboration skills. that in creativity (creative thinking or divergent thinking) has characteristics, namely fluency, flexibility, originality and elaboration (details) related to students' thinking abilities, with the ability to think creatively, the more creative students have these characteristics. (Wang, 2011; Fajriah, 2017).

Creativity can be seen as a product of creative thinking, while creative activities are learning activities aimed at encouraging or encouraging students to think creatively. Efforts are made to enhance student creativity through the use of attractive learning models such as POE and mind mapping models. (Amirullah et al., 2019). These models are capable of increasing student creativity, i.e., in the POE model, there are activities to make observations, with these activities, students are trained to explore and gather information by finding their own ideas about the material that has been studied and making students more enthusiastic about learning. (Sari, 2015). Whereas in the mind mapping model, the teacher needs to create teaching and learning situations that give students many opportunities to solve problems, to carry out several experiments, to develop students' ideas or concepts, because mind mapping requires students to take notes from the material presented by the teacher into creative notes. Like using symbols, images that are a step in the development of creativity (Sholihah, 2015). There are many efforts to develop student creativity, in particular, the ability to think in detail and student creativity through mind mapping.

\section{Conclusion}

In this study, we present the advantages of mind mapping as a method of describing the combination of creativity and creative thinking skills of students. Mind mapping shows a more concise and better picture of the hierarchy of creative ideas and scientific knowledge. This is very important for instructional designers who want to generate new ideas continuously. By providing a comprehensive idea map in one visual cue, students can reduce their work memory load and see problems from a broad perspective.

\section{References}

[1] Amirullah, G., Suciati, R., Handayani, D., \& Susilo, S. (2019). The Impact of Predict Observe Explain ( POE ) strategy against student' s critical thinking ability. Biodik: Jurnal Ilmiah Pendidikan Biologi, 5(2), 173-180.

[2] BSNP. (2006). Badan Standar Nasional Pendidikan. Permendiknas RI No. 22 Tahun 2006 Tentang Standar Isi untuk Satuan Pendidikan Dasar dan Menengah. Depdiknas.

[3] Buzan, T. (2008). Buku Pintar Mind Map. PT Gramedia Pustaka Utama.

[4] Čančer, V. (2014). Teaching Creative Problem Solving Methods to Undergraduate Economics and Business Students. Journal of Further and Higher Education, 38(4), 485-500.

https://doi.org/10.1080/0309877X.2012.726 968

[5] Darusman, R. (2014). Penerapan Metode Mind Mapping (Peta Pikiran) untuk Meningkatkan Kemampuan Berpikir Kreatif Matematik Siswa SMP. Infinity Journal, 3(2), 164-173.

[6] Fajriah, F. (2017). Learning Journal: Improving Teaching Strategies Through Students' Reflections. Sukma: Jurnal Pendidikan, $\quad$ 1(2), 301-327. 
https://doi.org/10.32533/01204.2017

[7] Fatonah, S., \& Prasetyo, Z. K. (2014). Pembelajaran Sains. Penerbit Ombak.

[8] Filsaime, K. D. (2008). Menguak Rahasia Berpikir Kritis dan Kreatif. Prestasi Pustaka.

[9] Heriadi, H. (2015). Penerapan Mind Mapping Pada Pembelajaran Biologi Konsep Sistem Pernapasan Manusia terhadap Peningkatan Aktivitas dan Hasil Belajar Siswa. Seminar Nasional XII Pendidikan Biologi FKIP UNS, 320-322.

[10] Hsu, Y., Peng, L.-P., Wang, J.-H., \& Liang, C. (2014). Revising the Imaginative Capability and Creative Capability Scales: Testing the Relationship between Imagination and Creativity among Agriculture Students. International Journal of Learning, Teaching and Educational Research, 6(1), 57-70. http://www.ijlter.org/index.php/ijlter/article/ viewFile/118/pdf

[11] Jahnke, I., Haertel, T., \& Wildt, J. (2015). Teachers' conceptions of student creativity in higher education. Innovations in Education and Teaching International, 54(1), 87-95. https://doi.org/10.1080/14703297.2015.1088 396

[12] Jankowska, D. M., Gajda, A., \& Karwowski, M. (2019). How Children's Creative Visual Imagination and Creative Thinking Relate to Their Representation of Space. International Journal of Science Education, 41(8), 10961117.

https://doi.org/10.1080/09500693.2019.1594 441

[13] Kalyuga, S. (2009). Knowledge Elaboration A Cognitive Load Perspective. Journal of International Learning And Instruction, 3(1), 402-410.

[14] Kisirkoi， F. K., \& Mse, G. (2016). Curriculum Implementation: Strategies for Improved Learning Outcomes in Primary Schools in Kenya. Journal of Curriculum and Teaching, 5(1), 19-26. https://doi.org/10.5430/jct.v5n1p19

[15] Leeds, A. J., Kudrowitz, B., \& Kwon, J. (2018). Mapping Associations: Exploring Divergent Thinking Through Mind Mapping. International Journal of Design Creativity and Innovation, 7(1-2), 1-14. https://doi.org/10.1080/21650349.2018.1463 178

[16] Malycha, C. P., \& Maier, G. W. (2017). The Random-Map Technique: Enhancing MindMapping with a Conceptual Combination Technique to Foster Creative Potential. Creativity Research Journal, 29(2), 114124.

https://doi.org/10.1080/10400419.2017.1302 763

[17] Munandar, U. (2014). Pengembangan Kreativitas Anak Berbakat. Rineka Cipta.

[18] Murray, J. W. (2016). Skills Development, Habits of Mind, and the Spiral Curriculum: A Dialectical Approach to Undergraduate General Education Curriculum Mapping. Cogent Education, 3(1). https://doi.org/10.1080/2331186X.2016.115 6807

[19] Nofiana, M., \& Julianto, T. (2018). Upaya Peningkatan Literasi Sains Siswa Melalui Pembelajaran Berbasis Keunggulan Lokal. Biosfer : Jurnal Tadris Biologi, 9(1), 24-35. https://doi.org/10.24042/biosf.v9i1.2876

[20] Olson, R. W. (1992). Seni Berfikir Kreatif. Erlangga.

[21] Permendiknas. (2006). Peraturan Menteri Pendidikan Nasional No 23 Tahun 2006 Tentang Standar Kompetensi Lulusan untuk Satuan Pendidikan dasar dan menengah. Direktorat Jenderal Manajemen Pendidikan Dasar dan Menengah.

[22] Pillay, Y., Lu, H. T., \& Funk, L. (2020). Introducing Mind Mapping as a Creative Counseling Modality. Journal of Creativity in Mental Health, 15(4), 474-481. https://doi.org/10.1080/15401383.2020.1746 721

[23] Putri, L. O. L. (2016). Mind Map Sebagai 
Model Pembelajaran Menilai Penguasaan Konsep dan Alat Evaluasi Menilai Kemampuan Berpikir Kreatif Siswa. Prosiding (SNPBS) Seminar Nasional Pendidikan Biologi Dan Saintek.

[24] Rolia, R., Rosmaiyadi, R., \& Husna, N. (2017). Pengaruh Model Pembelajaran Creative Problem Solving Terhadap Kemampuan Berpikir Kreatif Siswa Pada Materi Program Linier Kelas XI SMK. VOX EDUKASI: Jurnal Ilmiah Ilmu Pendidikan, 8(2), 72-82.

[25] Sari, N. W. N. (2015). Efektivitas Model POE dalam Meningkatkan Kemampuan Berpikir Elaborasi Pada Materi Larutan Penyangga. Jurnal Pendidikan Dan Pembelajaran Kimia Universitas Lampung, 4(3), 884-888.

[26] Sholihah, M. (2015). Penerapan Model Pembelajaran Mind Mapping untuk Mengingkatkan Kreativitas dan Hasil Belajar Siswa pada Pelajaran Ekonomi Kelas X IPS di SMA Negeri 8 Malang. Prosiding Seminar Nasional Pendidikan Ekonomi Dan Bisnis FKIP UNS. ISBN: 978M. (2015). Penerapan Model Pembelajaran Mind Mapping Untuk Mengingkatkan Kreativitas Dan Hasil Belajar Siswa Pada Pelajaran Ekonomi Kelas X IPS Di SMA Negeri 8 Malang. Prosidin.

[27] Sternberg, R. J. (2006). The Nature of Creativity. Creativity Research Journal, 18(1), 87-98.

[28] TIMSS. (2015). Assessment Framework. TIMSS \& PIRLS International Study Center.

[29] Wang, A. Y. (2011). Contexts Of Creative Thinking A Comparison On Creative Performance Of Student Teacher In Taiwan And The United States. Journal of Intenational And Cross Cultural Studies, 2(1), 1-9.

[30] Widyastuti, F., Helsy, I., Farida, I., \& Irwansyah, F. S. (2019). Implementation of
PDEODE (Predict, Discuss,

Explain,Observe, Discuss, Explain) Supported by PhET Simulation on Solubility Equilibrium Material. Journal of Physics: Conference Series, 1155(1). https://doi.org/10.1088/17426596/1155/1/012071

[31] Wu, J. J., \& Albanese, D. L. (2013). Imagination and creativity: wellsprings and streams of education - the Taiwan experience. Educational Psychology, 33(5), 561-581.

https://doi.org/10.1080/01443410.2013.8136 89

[32] Xu, X., \& Pang, W. (2020). Can Concept Mapping Facilitate Verbal Divergent Thinking? Creativity Research Journal, 00(00), 1-13. https://doi.org/10.1080/10400419.2020.1843 124

[33] Yang, K. K., Lee, L., Hong, Z. R., \& Lin, H. S. (2016). Investigation of Effective Strategies for Developing Creative Science Thinking. International Journal of Science Education, 38(13), 2133-2151. https://doi.org/10.1080/09500693.2016.1230 685

[34] Yunianta, T. N. H. (2014). Hambatan Seseorang Mengembangkan Kemampuan Berpikir Kreatif Matematis. Jurnal Ilmiah Pendidikan Universitas Kristen Satya Wacana, 16(2), 48-60. 
